\title{
Government Fiscal and Real Economy Responses to the Crises: Automatic Stabilisers versus Automatic Stabilisation
}

\author{
Jonas Fischer y Isabelle Justo
}

Revista de Economía y Estadística, Cuarta Época, Vol. 48, No. 1 (2010), pp. 11-40.

http://revistas.unc.edu.ar/index.php/REyE/article/view/3869

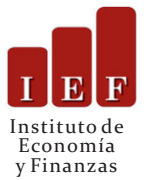

La Revista de Economía y Estadística, se edita desde el año 1939. Es una publicación semestral del Instituto de Economía y Finanzas (IEF), Facultad de Ciencias Económicas, Universidad Nacional de Córdoba, Av. Valparaíso s/n, Ciudad Universitaria. X5000HRV, Córdoba, Argentina.

Teléfono: 00 - 54 - 351 - 4437300 interno 253.

Contacto: rev eco estad@eco.unc.edu.ar

y Finanzas

Dirección web http://revistas.unc.edu.ar/index.php/REyE/index

Cómo citar este documento:

Fischer, J. e Justo I. (2010). Government Fiscal and Real Economy Responses to the Crises: Automatic Stabilisers versus Automatic Stabilisation. Revista de Economía y Estadística, Cuarta Época, Vol. 48, No. 1, pp. 11-40.

Disponible en: <http://revistas.unc.edu.ar/index.php/REyE/article/view/3869>

El Portal de Revistas de la Universidad Nacional de Córdoba es un espacio destinado a la difusión de las investigaciones realizadas por los miembros de la Universidad y a los contenidos académicos y culturales desarrollados en las revistas electrónicas de la Universidad Nacional de Córdoba. Considerando que la Ciencia es un recurso público, es que la Universidad ofrece a toda la comunidad, el acceso libre de su producción científica, académica y cultural.

http://revistas.unc.edu.ar/index.php/index

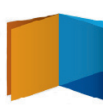


Revista de Economía y Estadística - Vol. XLVIII- º 1 - (2010) - pp. 11-40 Instituto de Economía y Finanzas - Facultad de Ciencias Económicas

Universidad Nacional de Córdoba - Argentina

\title{
Government Fiscal and Real Economy Responses to the Crises: Automatic Stabilisers versus Automatic Stabilisation*
}

\author{
JONAS FISCHER \\ DG ECFIN \\ European Commission \\ jonas.fischer@cec.eu.in \\ ISABELLE JUSTO \\ DGECFIN \\ European Commission
}

\begin{abstract}
This paper looks at the discretionary fiscal and real economy support measures introduced by EMU Member States in response to the crises. The analyses build on a data base assembled by the Commission on individual crises response measures with a view to survey the implementation of the European Economic Recovery Programme (EERP). The paper first provides a broad overview of the types of crises-related measures taken, including broad estimates of their budgetary dimension. On this basis it appears that on an aggregate level, the discretionary support has been in line with agreed principles of being timely, temporary and targeted. Member States with restricted fiscal space has overall taken a more restrictive stance than those with more room of manoeuvre. The paper then looks at how these discretionary measures complement the "automatic" budget stabilisation. It appears that, in budgetary terms, about half of the discretionary measures add to the areas already covered by automatic stabilisers while the other half address other areas such as investments, industrial sectors and vulnerable groups particularly hit by the crises. The overall experience
\end{abstract}

* The view expressed in the paper is that of the authors and do not necessarily represent those of the Commission. 
may suggest that it has been helpful with agreed ex-ante principles for how discretionary stimuli should be provided and that the provision of discretionary stimulus under such conditionality can work to strengthen the budgetary stabilisation capacity in a flexible way.

Key words: Automatic stabilisers, European Economic Recovery Programme (EERP), Budget, Discretionary policies.

JEL Classification: E6, H2, H3, H6.

\section{Resumen}

Este artículo analiza las medidas discrecionales fiscales y de apoyo a la economía real introducidas por los paises miembros de Unión Monetaria Europea en respuesta a la crisis. El análisis se realiza en base a datos recolectados por la Comisión Europea sobre medidas tomadas por cada país en respuesta a la crisis para evaluar la implementación del Programa de Recuperación Económica Europea. El artículo provee una extensa revisión de los tipos de medidas tomadas relacionadas con la crisis, incluyendo estimaciones de su dimensión presupuestaria. Con respecto a esto se encuentra que, a nivel agregado, el apoyo discrecional ha estado en línea con los principios aceptados de ser oportuno, transitorio y selectivo. Los Estados Miembros con capacidad fiscal más limitada en general han adoptado una postura más restrictiva que los que tienen más margen de maniobra. En el documento se analiza cómo estas medidas discrecionales complementan la estabilización presupuestaria "automática". Se encuentra que, en términos presupuestarios, cerca de la mitad de las medidas discrecionales apoyan a áreas y a cubiertas por los estabilizadores automáticos, mientras que la otra mitad apoya otras áreas como inversiones, sectores industriales y grupos vulnerables particularmente afectados por la crisis. La experiencia en general puede sugerir que los estímulos discrecionales han sido de gran ayuda $y$ han estado de acuerdo con los principios preestablecidos de cómo deben ser provistos y que la implementación de este tipo políticas discrecionales pueden fortalecer la capacidad de estabilización presupuestaria de una manera flexible.

Palabras clave: Estabilizadores Automáticos, Plan Europeo de Recuperación Económica (PERE), Presupuesto, Políticas Discrecionales.

Clasificación JEL: E6, H2, H3, H6. 


\section{INTRODUCTION}

The economic crises have provoked substantive policy responses, in the EU and globally. The role of discretionary fiscal stimulus as an ingredient in a successful policy response was initially vividly debated and the stance among EU policy makers was arguably relatively cautious. The cautiousness was rooted in a consensus, built-up over many years and backed up by historical evidence, ${ }^{1}$ that discretionary fiscal stimulus suffers from problems related to the design, implementation and reversibility of measures. Therefore, in normal circumstances the fiscal stabilisation job should be restrained to the "free play" of the automatic stabilisers as they are relatively well targeted and by nature also timely and temporary. Moreover, it has been argued that in the EU/ euro area the size of government is relatively large implying that also automatic stabilisers are sufficiently large. ${ }^{2}$

Nevertheless, as the depth of the crises manifested itself with more strength, and as stimulus through monetary policy appeared partially impaired, the worries of entering into an outright depression led to a change of hearts. Despite quickly deteriorating fiscal positions, the concern about using discretionary fiscal policy for stabilisation purposes were overridden by the greater concern about economic developments and the risk of economies being locked into a state of depression. Policy makers in the EU/euro area thus opened up to the idea that it would be appropriate with additional fiscal stimuli given that this was not a normal downturn. Discretionary fiscal stimulus was seen as an insurance policy, both from an economic perspective, to reduce the risk of a depression, and possibly also from a political economy perspective to get acceptance from tax payers for the much larger public efforts to support the financial system. Against the background of the simultaneous discussions at global level in the G20 context, in the EU, this stimulus policy was manifested in the so-called "European Economic Recovery Plan" (EERP) adopted by the European Council in December 2008 based on a Commission proposal. ${ }^{3}$ In essence, the EERP called for a co-ordinated EU crises response including a fiscal stimulus of overall at least $1.5 \%$ of GDP over 2009-2010 where measures should be "timely, temporary and targeted". Out of this Member States were asked to contribute with $1.2 \%$ of GDP, where the size of national

\footnotetext{
1. See for example the annual Commission reports "Public Finances in EMU".

2. See for example Deroose, Larch, Schaechter (2008).

3. COM (2008) 800 final, 26/11/2008, 'A European Economic Recovery Plan'. Available at: http://ec.europa.eu/commission_barroso/president/pdf/Comm_20081126.pdf
} 
contributions should take into account fiscal space, whereas the remaining $0.3 \%$ of GDP should come from EU level actions. Against this background the objective of this paper is to give an overview of how the discretionary stimulus under the EERP has been distributed in euro area Member States and how this support has complemented the stabilisation provided by the automatic stabilisers.

The paper is organised as follows. On the basis of the Commission "EERP data base", section 2 provides a broad overview of the crises response measures taken in euro area member states. This includes the division of measures across policy objectives as well as their budgetary dimension including whether they are temporary or permanent. Section 3 then goes into more detail examining the sub set of discretionary measures that could be seen to top-up the automatic stabilisers. In section 4 follows concluding remarks.

\section{Crises Support Measures in the Euro Area: An Overview}

The EERP called for a co-ordinated fiscal stimulus equivalent to $1.5 \%$ of EU27 GDP over 2009-2010, whereof $1.2 \%$ of GDP should come from Member States. The stimuli measures should follow the "TTT principles", that is, being timely, temporary and targeted, whilst taking into account national starting points. In addition, priority should also be given to structural reform measures as part of the Lisbon strategy for Growth and Jobs. There has been continuous follow up exercises where the assessment of the Commission and the Council so far has been positive in that broadly these ambitions have been met. ${ }^{4}$ That is, the implementation of the EERP has been showing good progress and been in line with the principles agreed in the EERP. The objective here is not to confirm or question this assessment but merely to provide an overview of the support measures to the real economy implemented by euro area Member States on the basis of the measures included in the EERP data base ${ }^{5}$ (see Box 1 for a description of the structure of the data base).

4. Commission reports of the follow-up of the EERP have been presented in June 2009 and December 2009. See Progress report on the implementation of the European Economic Recovery Plan - June 2009 and dito December 2009, available at http://ec.europa.eu/financial-crisis/documentation/index_en.htm

5. For a detailed overview of the measures in the data base in May 2009, see European Commision (2009). 


\section{Box 1: Structure of the EERP database}

The EERP database refers to reforms and measures that can help with the recovery process in the short-term, i.e. during 2009 and 2010, irrespective as to whether they were devised specifically as a response to the crises. The data base include information on reforms and measures that are relevant for (i) sustaining aggregate demand, (ii) sustaining employment, (iii) addressing competitiveness problems (iv) protecting incomes of disadvantaged groups during that period. Financial market rescue packages are not included in the database. However, consolidation measures are included in the database. In practice, there is no clear separation between measures that are of a short term fiscal nature or a longer term structural nature. Accordingly, some "stimulus measures" can be purely of a budgetary and temporary nature or also be structural reforms with a budgetary impact. Measures have been classified according to four broad types of policy objectives with sub categories:

- Measures and reforms aimed towards supporting industrial sectors, businesses and companies, with sub-categories (i) Easing financing constraints for businesses/SMEs (ii) Sector-specific demand support (iii) Non-financial measures supporting business (e.g. regulatory) and (iv) Sector-specific direct subsidies.

- Measures and reforms aimed at supporting a good functioning of labour markets, including (i) Promoting wage moderation (ii) Temporary working-time reduction (iii) Reduction of tax on labour (iv) Unemployment benefit system and social assistance and (v) Easing labour market transitions (training, placement, other job-search help).

- Measures and reforms aimed at supporting investment activity including (i) physical infrastructure (ii) energy efficiency and (iii) R\&D and innovation.

- Measures and reforms that support household purchasing power, including (i) income support, general, (ii) income support, targeted and (iii) household subsidy for certain type of goods/services.

- Budgetary consolidation measures, including (i) Pure budgetary consolidation measure. (ii) Financing of recovery measure. 


\begin{tabular}{|c|c|c|c|c|c|}
\hline \multirow[b]{3}{*}{$\begin{array}{l}\text { Member } \\
\text { States }\end{array}$} & \multicolumn{5}{|c|}{$\begin{array}{c}\text { Table B1 } \\
\text { Overview of the number of measures } \\
\text { in the EERP data base }\end{array}$} \\
\hline & \multicolumn{5}{|c|}{ Policy Type } \\
\hline & \begin{tabular}{|c}
1 \\
Supporting \\
Industrial Sectors, \\
Businesses and \\
Companies
\end{tabular} & $\begin{array}{l}2 \\
\text { Supporting a } \\
\text { Good Function- } \\
\text { ing of Labour } \\
\text { Markets }\end{array}$ & $\begin{array}{l}3 \\
\text { Supporting } \\
\text { the Investment } \\
\text { Activity }\end{array}$ & $\begin{array}{l}4 \\
\text { Supporting the } \\
\text { Households' } \\
\text { Purchasing } \\
\text { Power }\end{array}$ & $\begin{array}{c}5 \\
\text { Budgetary } \\
\text { Consolidation }\end{array}$ \\
\hline $\mathrm{BE}$ & 16 & 25 & 11 & 14 & 15 \\
\hline $\mathrm{DE}$ & 23 & 12 & 13 & 16 & 2 \\
\hline IE & 7 & 4 & 9 & 10 & 30 \\
\hline EL & 13 & 13 & 7 & 12 & 18 \\
\hline ES & 50 & 16 & 20 & 17 & 7 \\
\hline FR & 23 & 15 & 12 & 18 & 1 \\
\hline IT & 43 & 29 & 20 & 27 & 21 \\
\hline $\mathrm{CY}$ & 12 & 16 & 9 & 11 & 0 \\
\hline LU & 8 & 3 & 7 & 8 & 0 \\
\hline MT & 13 & 5 & 17 & 11 & 13 \\
\hline NL & 18 & 8 & 32 & 3 & 1 \\
\hline AT & 28 & 15 & 16 & 16 & 0 \\
\hline PT & 16 & 8 & 7 & 11 & 0 \\
\hline SI & 11 & 7 & 12 & 2 & 2 \\
\hline SK & 10 & 10 & 7 & 8 & 4 \\
\hline FI & 4 & 14 & 6 & 7 & 5 \\
\hline $\begin{array}{l}\text { TOTAL } \\
\text { EA } 16\end{array}$ & 295 & 200 & 205 & 191 & 119 \\
\hline $\begin{array}{l}\text { (\% of the } \\
\text { total) }\end{array}$ & 29 & 20 & 20 & 19 & 12 \\
\hline $\begin{array}{l}\text { In som } \\
\text { tives. F } \\
\text { also co } \\
\text { low pa } \\
\text { ket and } \\
\text { countin }\end{array}$ & $\begin{array}{l}\text { e cases, a meas } \\
\text { ar example, so } \\
\text { ntribute to supt } \\
\text { id can contribu } \\
\text { bolstering inc } \\
\text { ig" implies that }\end{array}$ & $\begin{array}{l}\text { ure can releva } \\
\text { ome labour ma } \\
\text { porting housel } \\
\text { ate both to su } \\
\text { ome of vulne } \\
t \text { the } 764 \text { euro }\end{array}$ & $\begin{array}{l}\text { ntly contribut } \\
\text { rket measure } \\
\text { old income. } \\
\text { oporting trans } \\
\text { able househo } \\
\text { area measure }\end{array}$ & $\begin{array}{l}\text { to multiple } \mathrm{p} \\
\text { involving tax } \\
\text { lso, tax reduc } \\
\text { itions on the } \\
\text { lds. The result } \\
\text { s are recorded }\end{array}$ & $\begin{array}{l}\text { licy objec- } \\
\text { reductions } \\
\text { ions on the } \\
\text { abour mar- } \\
\text { ng "double } \\
1010 \text { times }\end{array}$ \\
\hline
\end{tabular}


under different policy types. Measures have also been classified according to their duration. Temporary measures have a budgetary effect only in 2009 and/or 2010. They should be automatically reversed (e.g. measures with a limited budget envelope, a known ending date, or one-off measures). In that respect, investment projects are considered as temporary measures in the data base. Tax measures are considered as temporary only if the end date of the tax measure is indicated in the decision. If the reversal/change of the measure undertaken will require a new decision, it has been considered as permanent.

A detailed budgetary dimension (expenditures and revenues) of each measure for the year 2009 and 2010 is recorded in the database in millions of Euro, with an indication of the 'Off-budgets' or 'below the line' amounts, essentially loan and guarantees, which potentially could have structural and possibly budgetary effects in the medium term. Figures are recorded as a change relative to the year 2008, also in 2010 . In other words, if a measure is permanent, the amount of the stimulus is reported both for 2009 and 2010 , while one-off measures appear only for the year when they occur. It should be noted that the information is in gross terms both on the expenditure and revenue sides and refers to the general government sector and state, regional, local and social security budgets.

\section{II.1. The euro area budgetary dimension of EERP stimulus}

Euro area budget positions have deteriorated sharply in connection with the crises. According to the Commission Autumn Forecast (Table 1), on average, euro area deficits is projected to widen by almost $5 \%$ of GDP over 2009 and 2010 and the average deficit position in the euro area to approach $7 \%$ of GDP in 2010. Clearly the consolidation requirements in the years to come will be challenging. A fair share of this deterioration can be expected to be reversed in the recovery phase, in so far that it depends on the cycle. In the Commission autumn forecast it is estimated that the cyclical budget component explains about half of the deterioration in the euro area as a whole (column 3). Nevertheless, in this juncture the estimates of the cyclical budget component are possibly more uncertain than ever, given the difficulty in knowing what are really the representative output gap as well as budgetary sensitivity to the cycle. Uncertainty is also increased by that some tax bases arguably have been structurally reduced in connection with the crises and much of such revenue will therefore not return in a future recovery. ${ }^{6}$

6. See Commission 2009 Autumn Forecast for some further comments on this issue. 


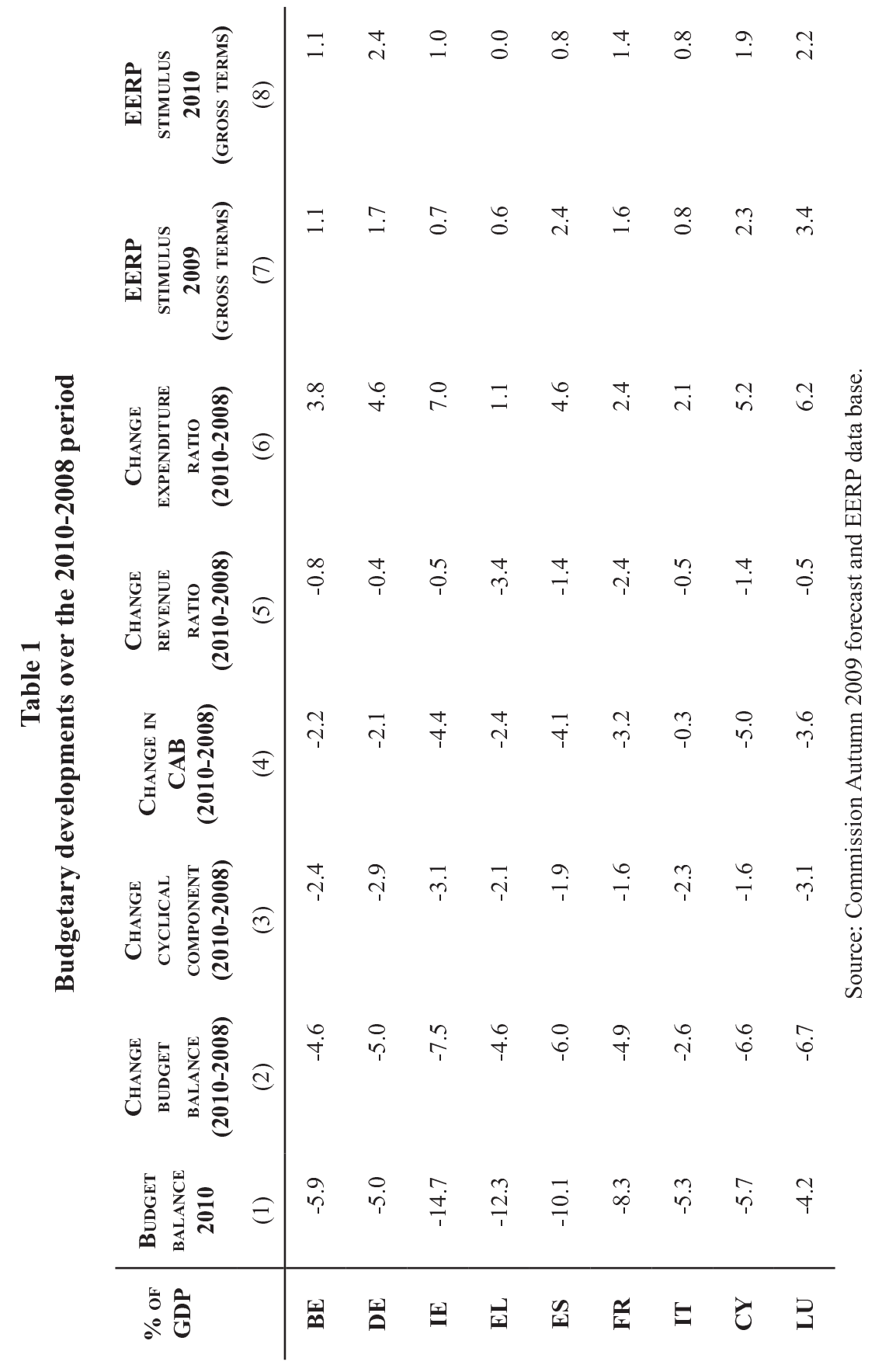




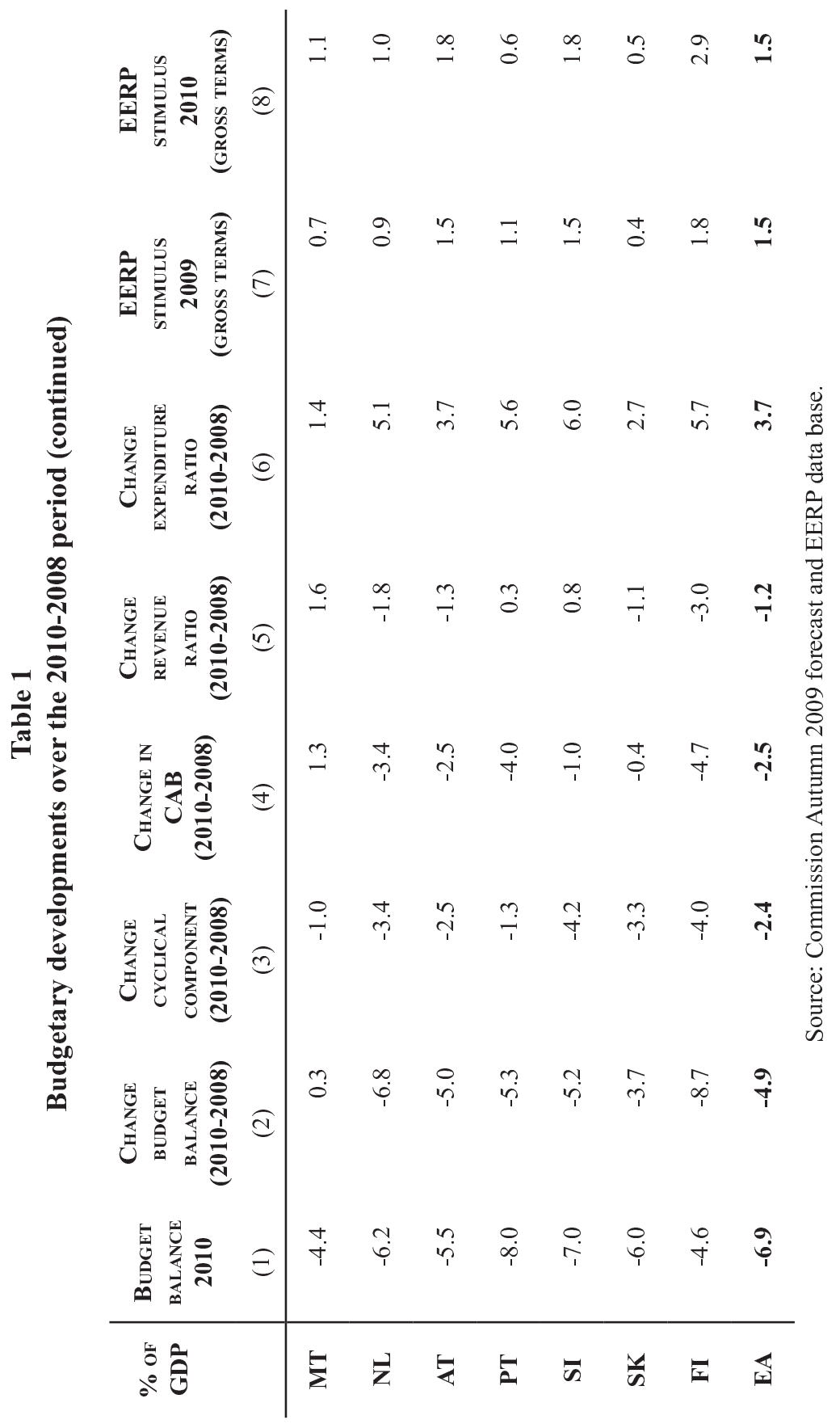


On the basis of the EERP data base, the volume of the discretionary stimulus is estimated to be $1.5 \%$ of GDP in 2009 and $1.5 \%$ of GDP in 2010. This is in gross terms and compared to 2008 and as such seems to achieve the $1.2 \%$ of GDP objective in the EERP with a margin. It should be noted that in some countries there has also been substantive measures taken in order to finance the stimulus or limit the budget deterioration given the lack of fiscal space (see Table 2). Therefore, in net terms the EERP stimulus is about a third lower than in gross terms ( $2 \%$ instead of $3 \%$ of GDP). Overall, these figures indicate that roughly about a quarter of the deterioration of budget positions between 2008 and 2010 could potentially be explained by the EERP stimulus. ${ }^{7}$ In other words, three quarters of the deterioration in budget positions is rather explained by other cyclical, structural or one-off factors.

\section{II.2. The national budgetary dimension of EERP stimulus}

The size of the EERP discretionary stimulus over 2009-2010 nevertheless differs substantially across Member States. This could partially reflect differences in the depth of the crises and thus the need for additional stabilisation efforts, over and beyond the automatic stabilisers. However, it is arguably a stronger reflection of that the room of manoeuvre in terms of deficit and debt levels as well as external imbalances varied across countries going into the crises, in other words, some countries had more fiscal space than others. ${ }^{8}$ As suggested by Table 2, discretionary stimulus efforts have been larger than average in Germany, Luxembourg and Finland. In all these countries the budget position was strong going into the crises and external imbalances limited. Additional stimuli have on the other hand been clearly below average in Ireland, Greece and Malta where the consolidation measures have more than off-set any stimuli. Efforts have also been relatively small in Portugal, Slovenia and Slovakia. For other countries, the situation appears to be more mixed. In some countries where the fiscal space should be restricted, the stimulus has in any case been relatively strong, for example Spain where most of the efforts have been concentrated in 2009 (whereas consolidation measures are larger 2010).

7. However, it should be noted that the information in the EERP data base is fully national accounts based, so the analysis here is only indicative, see also Box 1.

8. See section IV.3 in Public Finances in EMU-2009 where an indiactor of "fiscal space" is presented. 


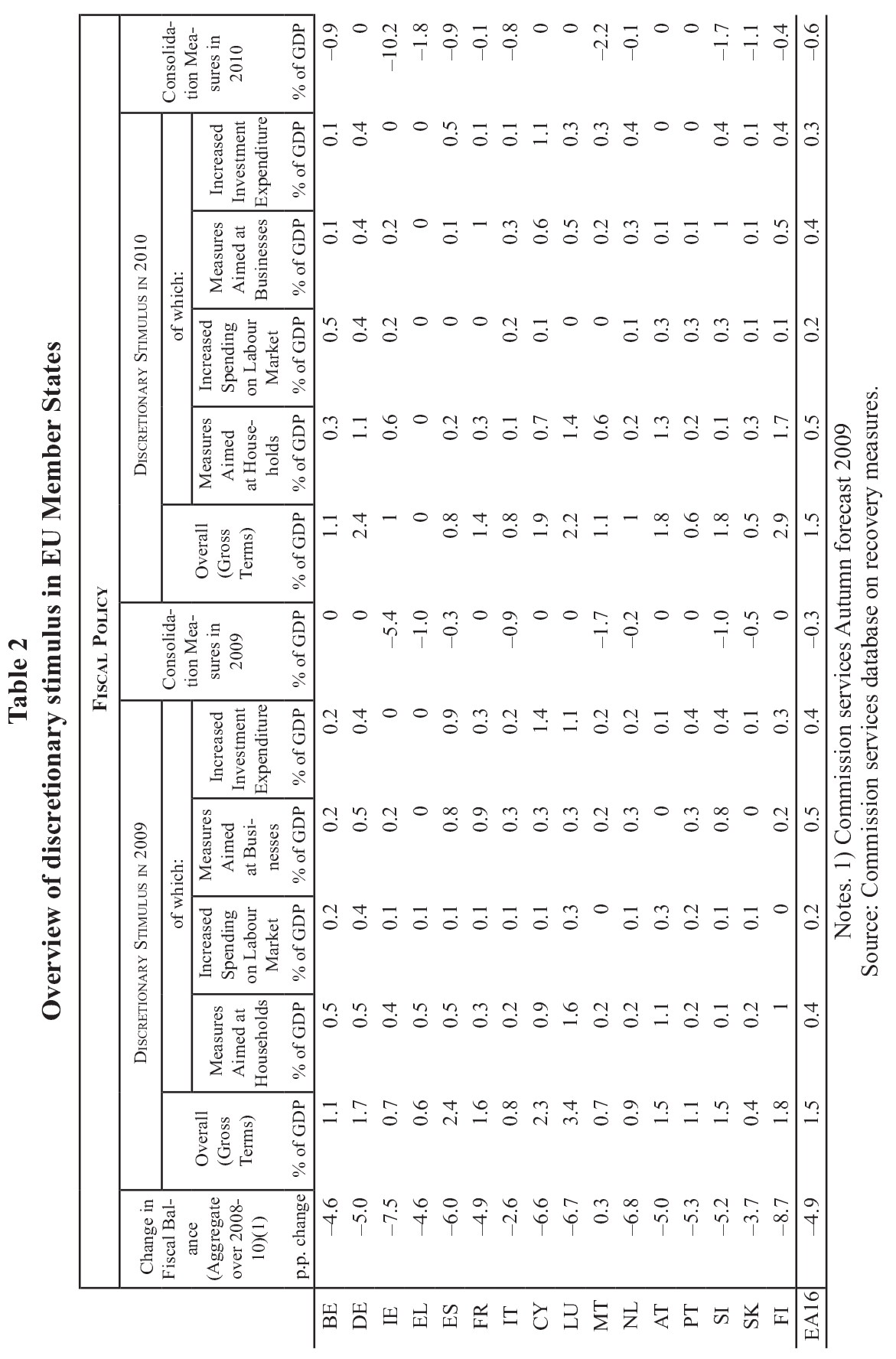




\section{II.3. The policy objectives of the EERP stimulus}

According to the principles of the EERP, the real economy stimulus should be well targeted in order to achieve the highest demand impact. The support measures in the data base have been classified under four different policy objectives (see Box 1), namely: support to households and vulnerable groups; support to labour markets; support to industry and business and finally investment support. ${ }^{9}$ In budgetary terms, Table 2 indicates that out of the total 3\% of GDP of support measures over 2009-2010, about $0.9 \%$ of GDP have been directed towards the support of households while the resources spent to support labour markets have been considerably less at $0.4 \%$ of GDP, possibly reflecting the lagged impact of the crises on labour market conditions and unemployment. Measures to support businesses and product markets make up about $0.9 \%$ of GDP and investments $0.7 \%$ of GDP. ${ }^{10}$ As regards the individual policy objectives the following broad observations can be made as regards the type of policies taken:

- Measures to support household purchasing power. General changes of income tax schemes have been implemented in several Member States which have the advantage of being transparent, easily implemented, unbiased towards specific sectors, and increase incentives to work. On the other hand, they may be less efficient since high income earners have a relatively low propensity to consume while they are often costly from a fiscal perspective, which may explain their limited scope in many Member States. ${ }^{11}$ Finally, a relatively large number of countries have introduced measures that target low income households although they often are of a quite limited overall size in terms of budget impact. As low income households also covers unemployed persons it would seem to be a group negatively hit by the crises.

- Measures and reforms aimed at supporting a good functioning of labour markets. Many of them facilitate flexibility within firms (through retraining and working time arrangement) or labour market transition between firms (through job placement, training, and encouragement to geographical mobility). Reduction of taxes on labour

9. The financial sector support schemes are not covered by the data base.

10. In terms of a simple measure counting, around $29 \%$ has been directed towards measures that support businesses, $20 \%$ to supporting labour markets, $20 \%$ to investment activities, and 19\% as support to households' purchasing power (including vulnerable groups). See table B1 in Box 1.

11. Even so, general tax reductions have been more pronounced in Member States where these tax cuts, in particular on labour income, have been part of a longer term structural policy agenda to lower taxes on labour. 
is applied in many Member States and can boost both labour demand and labour supply while supporting household purchasing power. As regards measures with the potential to directly affect wages in the short term they have been relatively scarce. There have however been measures to boost labour demand through reductions in social security contribution, cutting income taxes. Rebates on social security contributions to boost labour demand have been taken in a number of euro area members and have then typically been made conditional upon job creation. Many euro area countries have either introduced new forms of public support to flexible working time or temporary unemployment, or extended the duration and/or the level of already existing public support (these measures are dealt with further in the next section).

- Measures aimed at supporting industrial sectors, businesses and companies. Overall, there have been quite a number of initiatives taken in these areas across euro area countries and the budgetary amounts involved are in cases substantial. Almost all euro area countries have moved to counteract the drying up of credit for businesses in various ways. Measures also relates to the support of sectors particularly hard-hit by the crisis, that is, automotive, construction, tourism varying on the country. As regards demand measures, car-scrapping schemes have been implemented in several countries (FR, PT, IT, ES, LU, DE, AT, SK, CY, NL, IE) with the German version being the most extensive example. Other sectors where demand support measures have been taken are construction (FR, IE, ES).

- Measures to support investment activity. This relates to physical infrastructure, R\&D and energy efficiency. The prominence attached to public investment in recovery efforts varies considerably across Member States, with the largest increases in spending as a percentage point of GDP observed in DE, CY, ES, NL, SI while support to investment in euro area countries facing larger budgetary restrictions are less. Nearly all Member States have announced measures aimed at supporting investment in physical infrastructure. By type of physical infrastructure, a majority of the measures aim at supporting investment in transport infrastructure. The biggest group of them are related to the road and/or railway sectors. 


\section{II.4. The temporary versus permanent dimension of EERP measures}

According to the principles of the EERP, the stimulus measures should be of a temporary nature unless they are part of a longer term reform agenda with a positive structural impact. Therefore, the measures in the data base have also been classified as being "temporary" or "permanent" in terms of their budget impact (see Box 1 for classification criteria used). The information has admittedly not always been complete and the dividing line between the two concepts not always fully clear.

On the basis of the classification made in the data base, out of the $1.5 \%$ of GDP of overall stimulus in $2010,0.6 \%$ of GDP is classified as being of a temporary nature, thus implying that their budgetary impact should fade off. In the context of the accumulated 3.0\% of GDP discretionary stimulus over 2009 and 2010, this suggests that the large majority share of the budgetary impact would indeed be of a temporary nature. Looking at the temporary measures in the field of labour markets and income support, they amount to $0.2 \%$ of GDP in 2009 and 2010. In this category, most measures have well-known ending dates or budgets clearly limited in time. The proportion of permanent measures to support household's purchasing power is also significant: $0.3 \%$ in 2009 increasing to $0.6 \%$ of GDP in 2010 and the measures concerned are concentrated in the field of labour taxation and income support. The budgetary impact of temporary measures to support business is amounts to $0.4 \%$ of GDP in 2009 and $0.2 \%$ in 2010. Of course, there is also a fairly large amount of off budget measures that should be considered in this context, including loans and guarantees. However, these measures do not affect public deficits in the immediate future. Still, in 2010, $0.9 \%$ of GDP consists of permanent measures with a durable impact on budget balances. The bulk of these permanent measures (equivalent to $0.5 \%$ of GDP) are aimed at supporting household purchasing power and a proper functioning of labour market, mainly via labour tax cuts. Their true motivation is often to strengthen incentives to work and is thus part of a longer term agenda. At a country level, Germany, Finland, Luxembourg and Austria seem particularly concerned. 
Table 3

The temporary versus permanent dimension of EERP measures (\% of GDP)

\begin{tabular}{|c|c|c|}
\hline TOTAL TEMPORARY MEASURES & 1.1 & 0.6 \\
\hline $\begin{array}{l}\text { 1. Supporting industrial sectors. } \\
\text { businesses and companies. }\end{array}$ & 0.4 & 0.2 \\
\hline $\begin{array}{l}\text { 2. Supporting a good functioning } \\
\text { of labour markets. }\end{array}$ & 0.1 & 0.2 \\
\hline $\begin{array}{l}\text { 3. Supporting the investment } \\
\text { activity. }\end{array}$ & 0.4 & 0.2 \\
\hline $\begin{array}{l}\text { 4. Supporting the household } \\
\text { purchasing power. }\end{array}$ & 0.1 & 0 \\
\hline TOTAL PERMANENT MEASURES & 0.4 & 0.8 \\
\hline $\begin{array}{l}\text { 1. Supporting industrial sectors. } \\
\text { businesses and companies. }\end{array}$ & 0.1 & 0.3 \\
\hline $\begin{array}{l}\text { 2. Supporting a good functioning } \\
\text { of labour markets. }\end{array}$ & 0 & 0.1 \\
\hline $\begin{array}{l}\text { 3. Supporting the investment } \\
\text { activity. }\end{array}$ & 0 & 0 \\
\hline $\begin{array}{l}\text { 4. Supporting the household } \\
\text { purchasing power. }\end{array}$ & 0.3 & 0.5 \\
\hline $\begin{array}{l}\text { TOTAL EERP MEASURES IN THE } \\
\text { EURO AREA }\end{array}$ & 1.5 & 1.5 \\
\hline $\begin{array}{l}\text { BUGETARY CONSOLIDATION IN THE } \\
\text { EURO AREA }\end{array}$ & -0.3 & -0.6 \\
\hline
\end{tabular}

Source: Commission and own computations. 
Table 3 (continued)

EA16

2009

2010

\begin{tabular}{l|cc|cc}
\hline & $\begin{array}{c}\text { Temporary } \\
\text { Measures }\end{array}$ & $\begin{array}{c}\text { Permanent } \\
\text { Measures }\end{array}$ & $\begin{array}{c}\text { Temporary Permanent } \\
\text { Measures }\end{array}$ & Measures \\
\hline Belgium & 0.4 & 0.7 & 0.1 & 1 \\
Germany & 1.2 & 0.5 & 1 & 1.5 \\
Ireland & 0.1 & 0.6 & 0.2 & 0.8 \\
Greece & 0.6 & 0 & 0 & 0 \\
Spain & 2.2 & 0.2 & 0.5 & 0.2 \\
France & 1.3 & 0.2 & 0.4 & 1 \\
Italy & 0.6 & 0.2 & 0.7 & 0.1 \\
Cyprus & 1.8 & 0.5 & 1.6 & 0.4 \\
LuXembourg & 0.7 & 2.7 & 0.3 & 1.9 \\
Malta & 0.3 & 0.4 & 0.4 & 0.7 \\
Netherlands & 0.5 & 0.3 & 0.6 & 0.4 \\
Austria & 0.2 & 1.2 & 0.3 & 1.5 \\
Portugal & 0.8 & 0.3 & 0.3 & 0.3 \\
Slovenia & 0.4 & 1.1 & 0.6 & 1.2 \\
Slovakia & 0.4 & 0 & 0.5 & 0 \\
Finland & 0.5 & 1.3 & 0.6 & 2.3 \\
\hline EA16 & 0.4 & 0.6 & 0.8 \\
\hline & & 0.3 & &
\end{tabular}

Source: Commission and own computations.

\section{EERP Measures, Automatic Stabilisers} and Automatic Stabilisation

The recognition that discretionary fiscal stimulus can be a useful stabilisation tool has seemingly revived the interest in questions linked to automatic stabilisation and the complementary role of discretionary policies. Issues are whether there are efficient ways to strengthen the automatic stabilisers? Can discretionary stimuli become more like the automatic stabilisers, for example by increasing their automaticity by using ex-ante rules ensuring that additional 
stimuli is well targeted and temporary? Therefore, the recovery measures in euro area member states ${ }^{12}$ are classified according to what extent they deepen the impact of existing automatic stabilisation or whether they broadened their impact by focussing on recipients otherwise not covered. As above, the information draws on a Commission data base set up for the surveillance of the implementation of the European Economic Recovery Programme (EERP).

\section{III.1. Automatic stabilisers and their freedom to play: a budgetary versus a stabilisation perspective}

Euro area members benefit from the stabilisation provided by their large and encompassing welfare states. Indeed, it is today consensual advice, qualified on the availability of fiscal space, that the budget automatic stabilisers should be allowed to "play freely", including in downswings. However, what it actually implies in practice to let the automatic stabilisers "play freely" can be addressed from different sides of the same coin and below a differentiation is made between the "budgetary impact" side or the "stabilisation provision" side.

Arguably, the most common approach is to look at the automatic stabilisers from a "budgetary impact" perspective. Focus is then on estimating the cyclical budget component which is defined through the elements in the budget that vary systematically with the cycle, thus inducing to a counter-cyclical movement in the budget deficit position. The budget elements involved come from both the revenue side and expenditure side of the budget. On the revenue side, cyclically sensitive tax bases such as personal and corporate income taxes, social security contributions and consumption taxes are taken into account. Work has also been done to look at capital taxes linked to movements in asset prices. ${ }^{13}$ If tax rates are progressive it adds to the size of the automatic stabilisers. On the expenditure side, the measurement of automatic stabilisers is usually confined to unemployment benefits as unemployment rates vary counter-cyclically. It is more difficult to find clear automatic cyclical patterns for other expenditure areas, but also here work is on-going. ${ }^{14}$ In addition, there is a debate on where the line should be drawn between what is really automatic or discretionary. In some cases it can be observed that government behaviour is such that certain measures are taken over time systematically with the cycle albeit they formally require a discretionary decision and thus are not rules

12. While the EERP covers the whole EU27, in this paper for reasons of limited resources, the discussion has been limited to euro area countries.

13. See for example "Girouard and Price (2004)".

14. See for example "Darby and Melitz, (2008)". 
based. Overall, the budgetary impact from the automatic stabilisers is mainly associated with the tax side. According to the standard approach, the budgetary elasticity used to capture the size of the cyclical component (the elasticity is about 0.5 in the euro area on average and is multiplied with the estimated output gap), about $80 \%$ stem from the tax side (0.4) wile the remaining $20 \%$ stem from the unemployment benefit contribution $(0.1) .{ }^{15}$

In order to measure the "stabilisation impact" of automatic stabilisers, the basic approach is to contrast a situation when they are allowed to "play freely" with a situation when they are restricted or "turned off". ${ }^{16}$ There are several technical options available to do this, but in principle a simulation is made where the impact on growth when automatic stabilisers are playing freely is compared to the situation when the fluctuation in budgetary revenues are fully compensated by tax hikes and expenditure increases by expenditure cuts. This approach follows the apparent logic of the definition of automatic stabilisers from the budgetary impact side. Nevertheless, an issue to consider is what the results imply in terms of stabilisation provision and the support provided to households (in a down turn) through the automatic stabilisers. In particular, if the benchmark for comparison is the case when all taxes and expenditures are lump sum (or alternatively a strict budget annual budget balance rule applies) the question arises what the results actually implies, especially if the underlying question is how much stabilisation or support that has been provided through the budget.

Consider an illustrative example. A household before a downturn earns 100 and faces a proportional income tax rate of $50 \%$. It then pays 50 in tax, leaving a net income of 50. If in the downturn the household gross income fall by half to 50 , it then pays 25 in taxes, seeing its net income half to 25 . Thus, government tax revenue falls by 25 . If the benchmark is proportional taxes then one would conclude that there is no stabilisation provided. However, arguably, if the benchmark used instead is lump sum taxes (as described above) this would be described as a case with a support of 25 to households from the automatic stabilisers through the tax side. Nevertheless, household income fall by half and the fact that the governments abstain from raising the tax rate to $100 \%$, in order to keep tax income at 50, appear to be a rather indirect and "virtual" stimulus seen from the point of view of households.

From the other side of the coin, i.e. the "stabilisation provision" side the perspective is reversed and it is in fact the non-cyclicality of government

15. See "Girouard and Andre, (2005)".

16. See for example Sekkat, van den Noord, Buti, Martinez-Mongay (2002). 
expenditures that provide the bulk of the automatic budget stabilisation. The basic mechanism is that the majority of government expenditures are not cyclically sensitive, and thus not cut or increased in a rules based and pro-cyclical way, which provides a large block of stability in the economy. This is not new, it is a common empirical conclusion that the degree of stabilisation tend to increase with the size of government. ${ }^{17}$ From this perspective, letting the automatic stabilisers to "play freely", in a down turn, implies focussing on that:

- Planned non-cyclical expenditures are not cut;

- Unemployment benefits are paid according to set rules and are not cut;

- That there is full financing, through borrowing, of expenditures despite the fall in revenues, i.e there are no pro-cyclical tax hikes to compensate for falling revenues.

In a debate on whether and how the automatic stabilisers can be strengthened it arguably makes a difference whether the discussion is framed around a definition of automatic stabilisers seen from the "budgetary impact" or "stabilisation provision" perspective as described above. Inputs in this debate seemingly often take a budgetary impact perspective as the starting point and therefore focus on the revenue side looking at the progressivity of tax rates, temporary changes in tax rates and, on the expenditure side, temporary increases in the generosity of the unemployment benefit system. However, if the final objective is to strengthen automatic stabilisation, then mechanisms to ensure that government non-cyclical expenditures are financed to be spent according to plan in bad times, not suffering from cuts, should also stand in focus together with mechanisms in good times to ensure that expenditures meant to be temporary do not become permanent. Indeed, there is an asymmetry at play here where in many countries, over time, expenditures have been raised permanently in good times leading to a gradual increase in the size of the public sector and tax pressure over time, possibly leading to higher inefficiencies in the economy.

\section{III.2. An overview of the EERP stimulus measures in relation to automatic stabilisers}

The discretionary stimulus measures taken and planned by euro area member states in the context of the EERP are examined below from an automatic stabilisation perspective. The typology allows for observations that are relevant in a more general discussion on how to strengthen automatic stabilisation and how discretionary stimulus would fit in this context.

17. See for example Fatas, Mihov, (2001). 
A distinction can also be made between "direct" stabilisation measures referring to measures that add additional support to the economy and "indirect" stabilisation measures that defend against pro-cyclical volume cuts.

- Discretionary measures that add on top of the automatic stabilisers: expenditure side

1) Top up of unemployment benefits.

2) Financial resources for agencies, local government etc, to finance planned expenditures including public employment.

- Discretionary measures that add on top of the automatic stabilisers: revenue side

3) Changes in tax rates (income, corporate or consumption taxes) and social security contribution rates, including to what extent there is an impact on progressivity.

- Discretionary measures that provide stimulus complementing automatic stabilisers

4) Investments over and beyond original plans, additional benefits to targeted and vulnerable groups, other.

Indeed, given that the automatic stabilisers are generally not designed with stabilisation provision as the primary objective, ${ }^{18}$ and that this thus to a large extent is a by-product, it is not obvious that, depending on the type and size of the shock, ${ }^{19}$ the stabilisation provided is sufficiently well targeted. An issue to examine is therefore how much of the discretionary stimulus provided under the EERP that relate to areas outside the coverage of existing automatic stabilisers and how much that has directly built on the existing structures of automatic stabilisers.

At an aggregate level, Table 4 suggests that, in budgetary terms, the split is fairly even between measures that build on, and thus deepen or broaden, the provision of automatic stabilisation and other stimulus measures, for example measures that relate to increased investment expenditures which is the ticket item together with additional support to households and vulnerable groups. Looking instead at the consolidation measures, Table 5 suggests that there have been noticeable pro-cyclical cuts in public expenditures (worth $0.2 \%$ of GDP) and increases of other taxes. The discussion below looks at these elements in more detail, seen from the expenditure and revenue side of the budget.

18. The primary objectives of tax systems are rather concerns linked to financing, equity and efficiency.

19. Indeed, it is often remarked that if the there is a supply shock the automatic stabiliser scan be counter productive by postponing necessary adjustment. 
Government Fiscal and Real Economy Responses to the Crises...

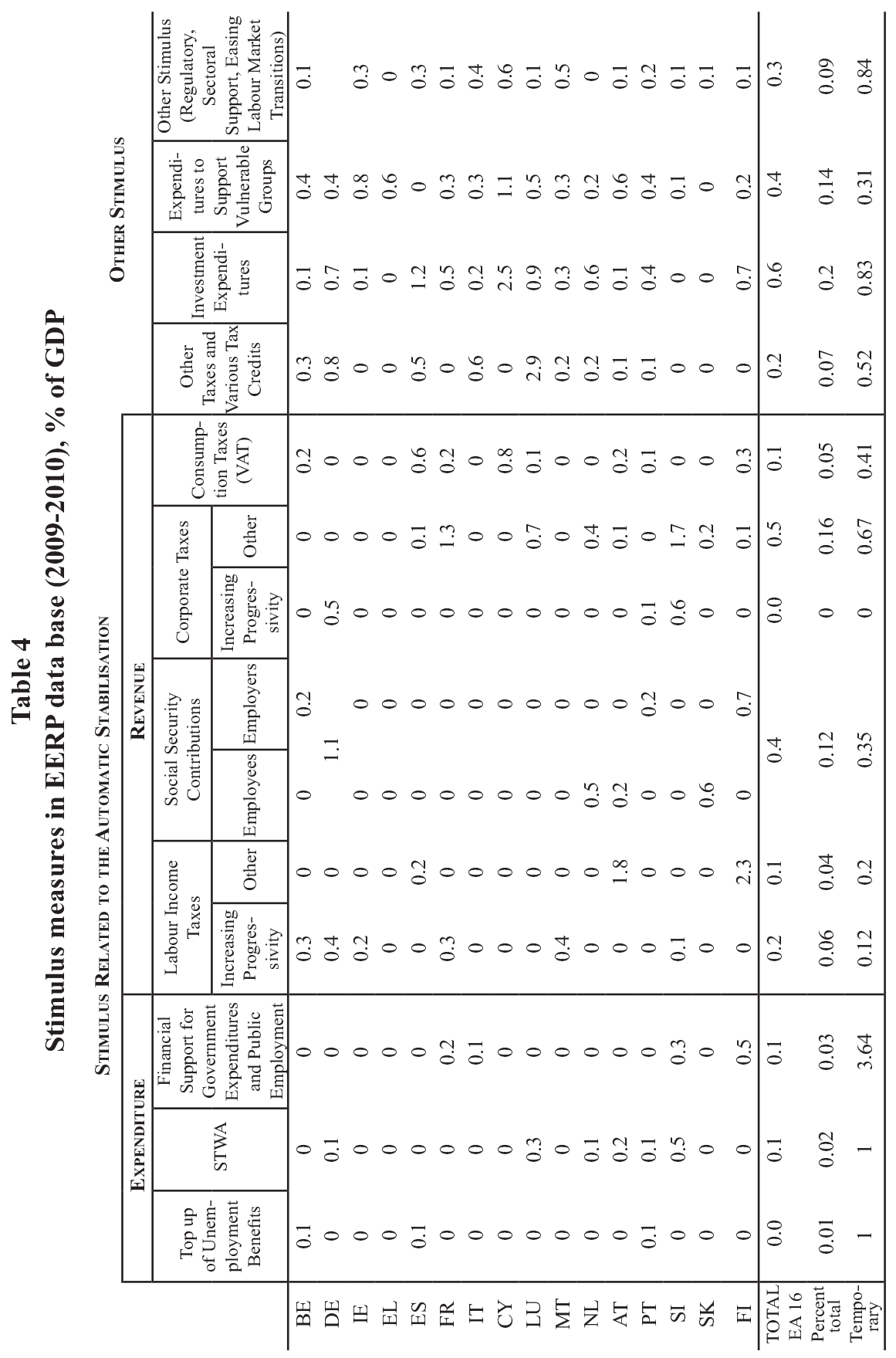




\section{Discretionary stimulus that build on the automatic stabilisers: expenditure side}

On the expenditure side, there are many examples of measures that either top up benefits directly or work to widen and soften eligibility criteria. While generally of a temporary nature, such measures do increase stabilisation properties if maintained. However, in this case there would be efficiency concerns related to the incentives to work looking forward. While measures that increase the generosity of unemployment systems arguably provide additional support in a direct way, measures that protect already planned demand provide support only indirectly. In the debate on fiscal rules it is recognised that annual budget balance rules can have a pro-cyclical impact, and that multi-annual rules are preferable from this perspective (such as the "close-to-balance over the cycle" rule in the Stability and Growth Pact). In this context the relationship between local government, where much of the consumption takes place, and central government, where much of the revenues are collected could be important as local level borrowing is in many cases restricted from the centre. However, the measures included in the data base do not reveal that this has been a particular concern so far. There are examples of measures providing additional support to local government but then mainly related to subsidies for additional investments at local level. More precisely:

- Measures that top up unemployment benefits. Measures under this heading has been taken in several countries (EL, IT, BE, PT, FR, ES), even though the budgetary impact has been overall rather small. Some countries decided to increase the generosity of unemployment benefits in level or in duration (in BE, EL, IT and PT). Others decided to extend their coverage to include temporary and interim workers (in FR, IT). In Spain a new allowance of $420 €$ for unemployed who have lost their eligibility to unemployment benefits was made available. In all these cases the measures are of a temporary nature. It should arguably be taken into account that the generosity of the existing unemployment insurance systems varies across euro area Euro area members in the starting points and accordingly also the need for additional top ups in times of rapidly deteriorating labour market conditions. The extension of benefit arrangements to groups formerly not insured, or who have lost their rights, can reach a large numbers of vulnerable households (recently laid-off workers, long term unemployed and other low-income households). 
- Short term working schemes ${ }^{20}$ In practice these schemes differ in nature across countries and it is not straightforward whether to see them as predominantly as a way to avoid lay offs, or whether they should be seen mainly as a way to top-up the salary for employees that otherwise would only get a part time based income. Indeed, in STW and temporary lay-off public schemes are also known as 'partial' or 'temporary unemployment', for example in Belgium, France and Luxembourg. Some Member States have introduced new short term working schemes (notably NL, PT, SI, SK), while others have extended the duration and/or the level of already existing ones (e.g. DE). Their coverage has been extended in BE, FR and IT to include employees on fixed-term contracts and in small companies. More generally, although STW schemes are justified in times of crisis, the main risk is that they can inhibit necessary restructuring, and this calls for strict time limits and eligibility criteria.

- Financial support to support to government, agencies etc, to support expenditures and public employment. In this category measures have in fact only been identified in a few countries. In France, central government VAT repayments to local authorities have been speeded up. A general move towards shorter lags in principle helps to strengthen the efficiency of automatic stabilisers. In Germany, there has been some support to structurally weak communes to carry out investments. In Italy the financing for the payment of social security benefits have been strengthened. In order to strengthen local government finances, Finland increased the share of corporate income tax revenues that are directed to municipalities and allowed for the upper real estate tax limit for local governments to be increased.

\section{Discretionary stimulus that build on the automatic stabilisers: revenue side}

Automatic variations in VAT rates could be one way to strengthen the automatic stabilisers, i.e. a rule based increase in good times neutralised by a rules based decrease in bad times, ${ }^{21}$ with the key feature that is

20. Short-time work (STW) can be defined as a temporary reduction in working time intended to maintain an existing employer/employee relationship. It can involve either a partial reduction in the normal working week for a limited period of time, i.e. a partial suspension of the employment contract, or a temporary lay-off (zero hours' week), i.e. a full suspension of the employment contract. In both cases, the employment contract continues and is not broken.

21. See for example SOU (2002). 
could be a measure that could be quickly implemented and of substantial budgetary magnitude, shifting consumption demand in time. The key example in the EU in this category has nevertheless come from outside the euro area, namely the temporary general VAT cut in the UK. Also, in the euro area there have been some cuts in VAT rates albeit generally of a targeted nature. Stabilisation properties can also be strengthened by measures that increase the progressivity in tax systems. In this context there has been a wide set of temporary measures taken with a view to support low income households or low income earners. In general such measures are both well targeted and in line with strategies to strengthen work incentives. More precisely:

- Income taxes. Measures that relate to income taxes have been taken in about half of euro area countries and in several countries these are relatively substantial. To a large extent these measures have been permanent and this relates in particular to the income tax cuts in Finland and Austria, which broadly should be seen in a longer term agenda to reduce tax on labour and improve incentives to work. However, of course, to some extent these measures reduce the future degree of automatic stabilisation. Beyond these broader measures, quite a few countries have taken other income tax measures that indirectly increase the degree of progressivity, such as reduction in the bottom personal income tax rate (DE) or for low income earners (FR). In MT income tax bands have been revised by broadening the tax free range of household income, thus raising progressivity.

- Social Security Contributions. For the euro area as a whole, measures with a view to cut social security contributions have been substantial even though actions have concentrated to a few countries and then in particular the temporary reductions in Germany. In the Netherlands, unemployment benefit premiums paid by employees have been abolished.

- Corporate taxes. Measures with a view to reduce corporate taxation have been taken in a majority of countries and corporate taxes have been lowered on a permanent basis in several euro area countries (FR, $\mathrm{DE}, \mathrm{LU}, \mathrm{SI}, \mathrm{SK})$ and on a more temporary basis in others (NL, PT, EL, ES). In Germany, a main measure relate to an increase in depreciation rates and interest ceilings. In Slovenia, tax rates have been cut and the deductibility of investment costs has been increased. Also, in France the depreciation rate of investments have been increased. 
- Consumption taxes. Changes to consumption taxes. In Belgium there has been a targeted cut of VAT towards construction. As indicated above, in France, central government VAT repayments to local authorities have been speeded up.

\section{Discretionary measures that add stimulus outside the areas covered by automatic stabilisation and consolidation measures}

About half of the overall stimulus provided under the EERP relate to measures targeted to areas outside the coverage of automatic stabilisation. The larger items are investments expenditures, where multipliers are potentially large, and towards households and vulnerable groups where in the current juncture the propensity to consume could also be relatively large. As pointed to in the previous section, there has also been substantial support to industry, in particular the automotive sector and construction sector, as well as measures to improve the access to finance.

As already pointed out (see Table 2), in terms of overall size, consolidation measures have been mainly concentrated to the countries with the most unbalanced fiscal positions, such as Ireland and Greece where the former have applied a broad based approach. In terms of the concentration of measures, Table 5 suggests that pro-cyclical cuts in public employment and wages have played a role, indicating that the automatic stabilisation has been reduced. A general positive feature is that investment spending has generally been protected. As regards tax increases, measures have concentrated on "other taxes".

In the case where the discretionary stimulus could be seen as a top up of the automatic stabilisers, a question is how much this has implied a "deepening", in terms of increasing their impact, and how much can been related to a "broadening" in terms of extending the coverage of recipients. For example, one way to increase the stabilisation properties of tax systems is to reduce the lags between economic activity and the ensuing tax payments. ${ }^{22}$ The smaller the lag the higher is the stabilisation properties and measures contributing towards this end therefore strengthen the stabilisation properties. ${ }^{23}$ In particular, corporate income tax is paid with a lag on the basis of the income in previous years. There are some examples of measures that move in this direction that is, shortening the lags in the system, for example quicker repayments of VAT in some countries.

22. Baunsgaard and Symansky (2009).

23. It can be noted that in the estimation of the standard budgetary elasticity to the cycle by the OECD, a correction for the lag structure in corporate and personal income tax structures have been introduced (Girouard and André, 2005). 


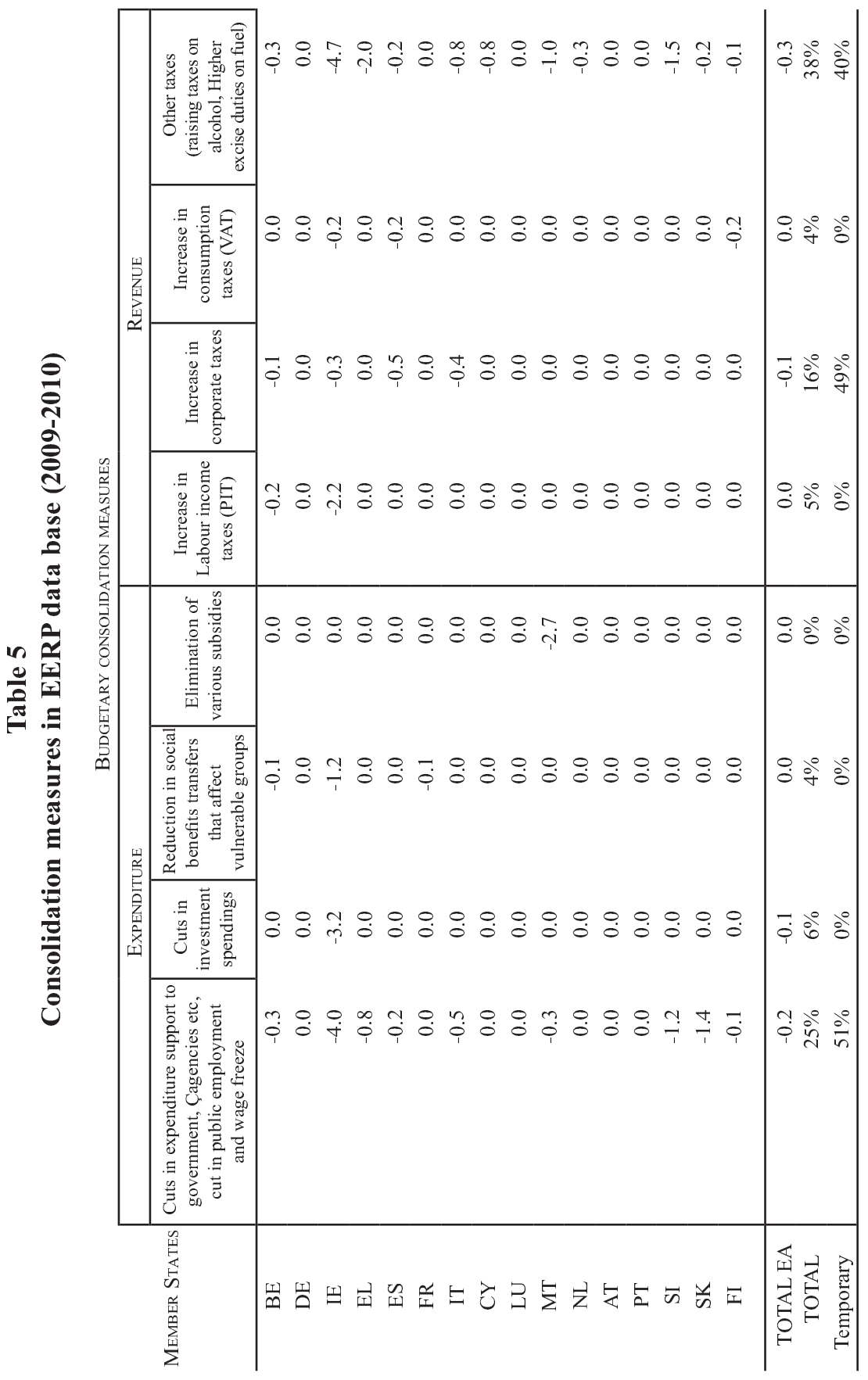




\section{Concluding remarks}

Euro area countries have addressed the impact of the crises by a broad use of the budgetary instruments available, including discretional fiscal stimuli. Generally, the automatic stabilisers have been allowed to "play freely" in the sense that the cyclical budget impact has, by and large, been allowed to influence budget positions without restraint, except in cases where the budgetary room of manoeuvre has been severely limited. For example, in Ireland substantial budget consolidation measures have instead been taken and in Greece such measures are currently in the pipeline.

The broad overview of the discretionary stimulus provided by euro area governments in the Commission's EERP data base indicates that they have been targeted towards investment expenditures, where multipliers are large, and towards households and vulnerable groups where in the current juncture the propensity to consume also should be relatively large. There has also been substantial support to industry, in particular the automotive sector and construction sector, as well as measures to improve the access to finance. It would seem that measures supporting labour markets have been relatively less prominent, possibly explained by the lag between growth and unemployment, even if the general impression is that in many countries the short-term working schemes have indeed helped to contain unemployment, even if only temporarily. Here, the absence of some type of measures, such as widening the access to early retirement schemes, which reduces labour supply, or large scale public employment creation schemes can also be positively noted as a break with the past. Moreover, most of the discretionary stimulus appears to be of a temporary nature while the bulk of stimulus measures with a more permanent impact have tended to relate to reductions in labour income taxes, contributing also to longer term agendas to reduce taxes on labour.

The crises have illustrated that while automatic stabilisation may be sufficient in normal cyclical conditions there is a role for discretionary policies in recessions and over-heating periods. The advantage of discretionary stimulus is that it can be designed to address the particular expressions of the crises/ over heating at hand. This time, for example, the financial sector, the automotive sector and a sizeable fall in investments have been key characteristics and this is also where most of the discretionary stimulus has been directed. Measures to strengthen the existing automatic stabilisers will most likely not help in this respect. Likewise, proposals for rules based discretionary stimulus schemes, conditioned on pre-specified indicator based triggers, will most likely suffer from the same weakness. 
Instead, the crises experience indicates the value of having a strategy and principles in place for how to best design and condition discretionary stimulus. The EERP could in this respect be seen as a success in that EMU members seem, so far, to have kept the agreed principles in mind in the national formulation of stimulus. In addition, the ability to also agree on common principles for the actual withdrawal of temporary measures to help ensuring that they indeed stay temporary is also positive. ${ }^{24}$ This experience can be built upon and the principles for what, how and under what conditions discretionary stimulus policies could play a positive role can be further developed, whilst acknowledging that there must be enough flexibility to allow the measures taken to be well targeted given that each crises/ over heating period will be different from the one before.

This argument is supported by another key lesson illustrated by the crises, namely the importance of having enough fiscal space going into a down turn not to be forced to adopt a pro-cyclical fiscal stance. In the coming years, the challenge of fiscal consolidation is a commonly shared one. This will require cuts in public expenditures and higher tax revenues. A gradual trimming of the size of government can promote efficiency but may also lead to less automatic stabilisation, given that the provision of stabilisation increase with government size. In this context, the impact of policies on the degree of automatic stabilisation should not be a primary concern. Indeed, there has been some research indicating that an optimal government size could lie as at such a low level as $40 \%$ of GDP, a level that most euro area countries have bypassed. ${ }^{25}$ Tax increases can on the other hand strengthen the automatic stabilisers but again at the possible expense of efficiency, of course depending on the design choices. Again, efficiency should be the primary concern and not the impact on stabilisation.

The overview of the discretionary measures taken by euro area members in this paper only provides some tentative indications at best, in particular as regards the interplay with the automatic stabilisers and the provision of automatic stabilisation. However, looking forward and with the benefit of increasing hindsight, there will surely be opportunity to draw more substantiated lessons from the experience with budget based stabilisation tools from this economic crises episode, hopefully in time to shape policies already in the upcoming recovery.

24. Council of the European Union, "Council conclusions on exit strategies for crises-related mesaures in labour and product markets", 16 March 2010, 7588/10.

25. Buti et al (2003). 


\section{REFERENCES}

Andres, Javier and Domenech, Rafael and Fatas, Antonio (2008). "The stabilizing role of government size", Journal of Economic Dynamics and Control, Elsevier, vol. 32(2), pages 571-593, February.

Baunsgaard, Thomas and Symansky, Steven (2009). "Automatic fiscal stabilizers", IMF position note, September 28.

Buti, Martinez-Mongay, Sekkat, van den Noord (2003). "Automatic Fiscal Stabilisers in EMU: A Conflict between Efficiency and Stabilisation?" CESifo Economic Studies, vol 49, pp. 123 - 140.

Darby and Melitz (2008). “Automatic stabilizers”, Economic Policy, October.

Deroose, Larch, Schaechter, (2008). "Constricted, lame and pro-cyclical? Fiscal policy in the euro area revisited" European Economy. Economic Papers. 353.

European Commission (2003). "Meeting the EU's budgetary requirements: national expenditure rules and fiscal relations across levels of government", Part V, "Public Finances in EMU-2003", N. 3 DirectorateGeneral for Economic and Financial Affairs.

European Commission (2009), "The EU's response to support the real economy during the economic crises: an overview of Member States' recovery measures", Occasional Paper 51, Directorate-General for Economic and Financial Affairs.

Fatás, Antonio and Ilian Mihov (2003). "The Case for Restricting Fiscal Policy Discretion" The Quarterly Journal of Economics, vol. 118, No. 4, pp. 1419-1447 Published by: The MIT Press.

Fatas, Antonio and Ilian Mihov (2009). "The Euro and Fiscal Policy," NBER Working Papers 14722, National Bureau of Economic Research.

Fatas, Antonio and Mihov, Ilian (2001). "Government size and automatic stabilizers: international and intranational evidence", Journal of International Economics, Elsevier, vol. 55(1), pages 3-28, October.

Girouard, Nathalie and André, Christophe (2005). "Measuring Cyclicallyadjusted Budget Bqlqnces for OECD countries", OECD Economic Department Working Papers No.434, July. 
Girouard, Nathalie and Price, Robert (2004) "Asset Price Cycles, Oneoff" factors and structural Budget Balances", OECD Economic Department Working Papers No. 391, July.

Seidman, Laurence and Lewis, Kenneth (2002). "ANew Design for Automatic Fiscal Policy”, International Finance, Blackwell Publishing, vol. 5(2), pages 251-84, Summer.

Statens Offentliga Utredningar (SOU) (2002) "Stabilization policy in the monetary union", 12 March. 